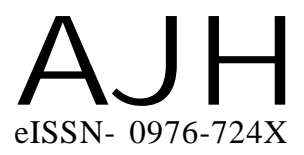

Received : 12.08.2014

Revised : 25.10.2014

Accepted : 07.11.2014
Members of the Research Forum

Associated Authors:

${ }^{1}$ Krishi Vigyan Kendra (A.A.U.),

KALIAPANI (ASSAM) INDIA

${ }^{1}$ Directorate of Extension Education, Assam Agricultural University, JORHAT, (ASSAM) INDIA
Author for correspondence : I. SARMA

Krishi Vigyan Kendra (A.A.U.), KALIAPANI (ASSAM) INDIA Email : irasarma@gmail.com
THE ASIAN JOURNAL OF HORTICULTURE

Volume 9 | Issue 2 | Dec., 2014 |386-389

Visit us -www.researchjournal.co.in
AT.

RESEARCH PAPER

DOI : $10.15740 / \mathrm{HAS} / \mathrm{TAJH} / 9.2 / 386-389$

\section{Response of french bean (Phaseolus vulgaris L.) to organic manure, vermicompost and bio- fertilizers on growth parameters and yield}

\section{SARMA, M. PHUKON ${ }^{1}$, R. BORGOHAIN ${ }^{1}$, J. GOSWAMI ${ }^{2}$ AND M. NEOG ${ }^{2}$}

ABSTRACT : A field experiment was conducted at farmer's field during Rabi season of 2011-12 in Jorhat district to study the effect of different combinations of organic sources of nutrients viz., vermicompost, FYM, rock phosphate along with bio-fertilizer on different growth parameters, yield and profitability of French bean cultivar Arka Anoop. The experiment was laid out in Randomized Block Design with four treatments and five replications. In this investigation, the results revealed that application of vermicompost $+\mathrm{FYM}+$ Rhizobium + rock phosphate $\left(\mathrm{T}_{2}\right)$ significantly increased the germination percentage $(87 \%)$, growth parameters and yield of the crop viz., plant height $(37.50 \mathrm{~cm}$ after 60 days of sowing), number of branches plant ${ }^{-1}$ ( 6.48 after 60 days of sowing), green pod length $(12.16 \mathrm{~cm})$, green pod number plant ${ }^{-1}(20)$, green pod weight $\left(300.05 \mathrm{~g} \mathrm{plant}^{-1}\right)$, dry weight of plant $(18.74 \mathrm{~g})$, number of seeds pod $^{-1}(6.08)$ than the remaining three treatments. There was no significant difference in days to 50 per cent flowering among different treatments. However, nodulation was maximum in the treatment $\mathrm{T}_{4}(41.88)$ and minimum in $\mathrm{T}_{1}(38.20)$ Nodules plant ${ }^{-1}$ in the treatment combinations $\mathrm{T}_{2}$ and $\mathrm{T}_{3}$ were at par. Highest yield $\left(14 \mathrm{t} \mathrm{ha}^{-1}\right)$ with maximum benefit : cost ratio (3.35:1) was obtained in the treatment combination $\mathrm{T}_{2}$ and the lowest $\left(7.00 \mathrm{t} \mathrm{ha}^{-1}\right)$ was obtained in the treatment $\mathrm{T}_{1}$ with minimum benefit : cost ratio $(2.50: 1)$. Though the yield was higher in the treatment $\mathrm{T}_{3}$ than $\mathrm{T}_{4}$, yet the benefit : cost ratio was more in the treatment $\mathrm{T}_{4}$. It may be due to high cost of vermicompost than FYM.

KEY WORDS : Vermicompost, FYM, Rhizobium, Growth, Yield, French bean

HOW TO CITE THIS ARTICLE : Sarma, I., Phukon, M., Borgohain, R., Goswami, J. and Neog, M. (2014). Response of french bean (Phaseolus vulgaris L.) to organic manure, vermicompost and bio-fertilizers on growth parameters and yield. Asian J. Hort., 9(2) : 386-389. 